\title{
Prosperity gospel and the culture of greed in post-colonial Africa: Constructing an alternative African Christian Theology of Ubuntu
}

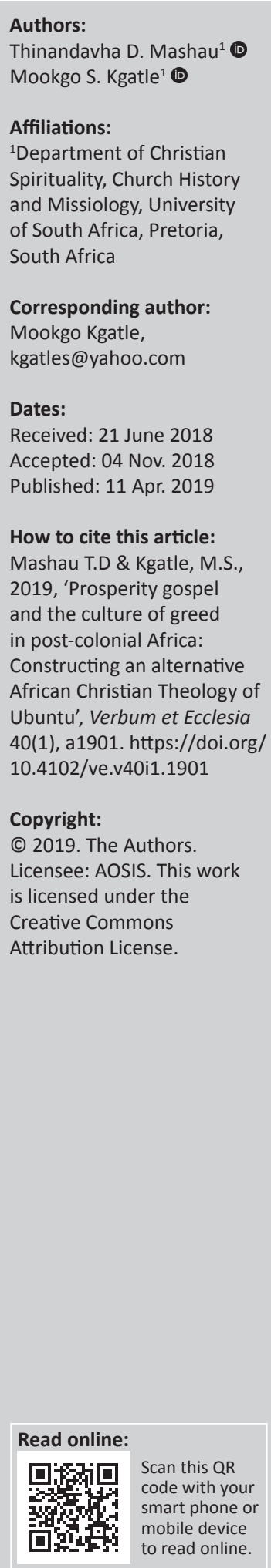

Christianity in post-colonial Africa is highly influenced and shaped by the prosperity message. The popular and materialistic gospel is sweeping across the continent like a gale-force wind, which is irresistible. Previous studies on prosperity gospel have indeed defined the concept as a global phenomenon and in an African context. This study is an interdisciplinary reflection on prosperity gospel and the culture of greed in post-colonial Africa. The study proposes the African Christian Theology of Ubuntu as an alternative to prosperity gospel. Ubuntu is prescribed here as an antidote to the culture of greed in prosperity gospel because it is a theology of life, care, solidarity, economic justice, hope and accompaniment.

Intradisciplinary and/or interdisciplinary implications: The paper challenges previous missiological perspectives on prosperity gospel and the culture of greed. The study proposes an African theology of Ubuntu as an alternative to prosperity gospel because it is a practical theology of life, care, solidarity, economic justice, hope and accompaniment.

Keywords: prosperity gospel; culture of greed; post-colonial Africa; African Christian Theology; Ubuntu.

\section{Introduction}

Christianity in post-colonial Africa is highly influenced and shaped by the prosperity message. The popular and materialistic gospel is sweeping across the continent like a gale-force wind, which is irresistible. This explosive growth of the prosperity gospel in Africa has received serious attention among researchers (see Anderson 1987; Gbote \& Kgatla 2014; Niemandt 2017). However, it is a matter that requires appraisal from time to time as correctly noted by Togarasei (2011) because of the massive nature of its influence on African Christianity, and exploitation that some Christians in Africa are exposed to as a result of its spread. Prosperity gospel encourages poor people to think positively and ignite the Godly power within them to instruct their cheque books or bank accounts to yield more (abundance) or to embrace the spirit of 'name it and claim it' when coming to material possessions. Poverty within this paradigm is defined as sin, laziness and lack of faith. Human suffering is also perceived as a lack of Godly favour (Quayesi-Amakye 2011:301). The prophets of this movement put emphasis on individual success but are silent about or have not developed a systematic theological analysis of economic injustice and social marginalisation that accompanies prosperity gospel.

In the South African context, the emergence of the so-called 'paparazzi pastors' like Pastor Ray McCauley of the Rhema Bible Church or the so-called 'celebrity pastors', as reported in the City Press (2011) of 16 April 2011, has prompted this study. This is coupled with the growing gullibility and abuse of ordinary and unsuspecting poor members who are fed grass, petrol and even snakes in their efforts to prove their faith in God (see Kgatle 2017:1). They are encouraged to give beyond measure for them to prosper and move out of poverty. This article seeks to demonstrate that whilst prosperity gospel has found a fertile ground in Africa, it continues to milk and disadvantage the very people it seeks to serve. It feeds into the culture of greed in church and society, thereby tapping into the capitalist economic global system. Our thesis in this article is that African Christianity must develop an alternative spirituality of liberation which taps into the African philosophy of life called 'Ubuntu'. We argue therefore for a systematic development of the theology of Ubuntu as an antidote to prosperity gospel. The question that we seek to answer is: What are the critical elements of Ubuntu that can assist African Christians to stand against the wrong elements of prosperity gospel as propagated by prosperity pastors over the correct biblical understanding of prosperity? In order to achieve this, this article will first look at the definition of prosperity as a global and African phenomenon and how it manifests itself (distinct characteristics) 
in the African soil. Having opened our eyes to see some of the snares associated with prosperity gospel when incorrectly understood and preached, this article will then conclude by proposing Ubuntu as the African contextual theology that can serve as an antidote to the poison of prosperity gospel as taught by prosperity, paparazzi and celebrity pastors who are preying on unsuspecting, gullible and abused members who blindly follow their leaders without applying the much needed spirit of discernment. The need for theological scrutiny and reflection is critical with regard to these current unconventional practices from new Charismatic churches as argued by Resane (2017:1).

\section{Prosperity gospel defined}

In the effort to propel phenomenal growth in terms of membership in their churches, prosperity preachers in America and elsewhere in the world have developed a theology of affluence called prosperity gospel (Ayegboyin 2006:73). Defining this theology is very complex and diverse. For the purpose of this article, the definition by Gifford (2004) is used and is captured as follows:

More significant than motivation in bringing about success is a theology that is called the prosperity gospel, or faith gospel, or the health and wealth gospel, according to which a Christian (through Christ's sacrifice on the cross) is already healthy and wealthy, and all he or she must do to take possession of health and wealth is to claim possession. (p. 172)

There are three distinct elements concerning the aforementioned definition of prosperity gospel, namely: (1) faith, (2) wealth and (3) health. It is critical for believers to exercise their faith as a means through which they are able to unlock or access their wealth and health. In the words of Hunt (2000):

... [H] ealth and wealth are the automatic divine right of all Biblebelieving Christians and may be procreated by faith as part of the package of salvation, since the Atonement of Christ includes not just the removal of sickness and poverty. (p. 333)

Sickness and poverty are not ideal and therefore not acceptable among Christians. At the core of prosperity gospel is the 'name it' and 'claim it' syndrome which is captured in the following words: 'The gospel of prosperity therefore teaches that all resources are there for people to claim them' (Togarasei 2011:344). Faith and positive confession thereof is viewed as the main condition for receiving abundance of material blessing (Young 1996:7). Accordingly, this material blessing 'includes the areas of financial prosperity and prosperity in the realm of physical health and well-being' (Young 1996:5). Failure to accumulate material possessions and good health can be accounted for as a sign of either attacks from the devil or lack of faith.

\section{Prosperity gospel as a global phenomenon}

Prosperity gospel is a global phenomenon. It is almost synonymous with Pentecostal-Charismatic churches with its roots in America (Niemandt 2017:205; Obadare 2016) and has grown to become a success story on almost all the continents. Kenneth Hagin, Kenneth and Gloria Copeland, Creflo Dollar, Robert Tilton, Joel Osteen are mentioned among others as the chief proponents of the American version of prosperity gospel (Young 1996:4). Anim (2010:67) further remarked that 'The Prosperity Gospel is significantly influenced by the teachings of E.W. Kenyon, Norman Vincent Peale and Robert Schuller'.

Prosperity gospel as a global phenomenon is riding on the wave of capitalism which is sweeping the global economy. Speaking of the African context, Umoh (2013:655) accedes that: 'Today in Nigeria (perhaps more than elsewhere) the spirit of capitalism sweeping through the whole world, is well adopted as an indispensable component of the Christian religion'. Neoliberalism seems to have found a partner in Pentecostalism in Africa to a point that Obadare concluded that: '... It is not unreasonable to suggest that, so far as prosperity is the raison deter of neoliberalism, Pentecostalism may rightly be seen as its religious mode or extension' (2016:4). The underpinning theology for such a movement is the theology of affluence (cf. Ayegboyin 2006:73). This theology has given birth to the gospel of 'greed and consumption'. It feeds into consumer culture. Members are encouraged to give in order to receive God's blessings (Achunike 2007:91; Gbote and Kgatla 2014:5). Mashau (2013) concluded that:

[...] giving has become more controversial in the city context because of the abuse at the hands of 'healing and prosperity' ambassadors who milk people in terms of requiring them to give more than the measure of grace accorded to them in the name of seeking God's blessings. (p. 78)

\section{The African face of prosperity gospel}

Prosperity gospel found fertile soil in Africa in what Gifford (2004:169) calls '[t]he explosion of charismatic Christian churches'. Prosperity gospel in Africa is synonymous with the Pentecostal-Charismatic Christianity. It is correctly asserted that: 'The impact of the Prosperity Gospel in contemporary African Christianity has been noted by scholars and it has often been associated with the development of new charismatic movements' (Anim 2010:67). As much as this movement has historical roots in the United States, it has grown to become a global phenomenon which has also found its home in Africa. Historical evolvement of prosperity gospel on African soil is well articulated by Gifford (2004:13) as follows: This prosperity gospel spread widely in Africa in the 1980s. One of its means of diffusion was Bonnke's 'Fire Conference' in Harare in April 1986. At this conference, which drew 4,000 delegates from 41 African countries, Kenneth Copeland conducted one of the key seminars on 'The Gospel and Prosperity'. Now this doctrine is associated with many of Africa's fastest-growing churches: the Rhema churches of South Africa and Zimbabwe; Andrew Wutawunashe's Family Church in Accra, Ghana; Benson Idahosa's Church of God Mission International in Nigeria and countless others. 
Prosperity gospel, with both its positives and negatives, has grown in Africa to become one of the successive stories that is paradoxically placed. There are distinct characteristics of prosperity gospel in the post-colonial era and the following can be cited:

It is the gospel of affluence: Africa is home to some of the richest religious leaders. Here, we can mention the likes of flamboyant pastors like the Nigerian pastor and Christian author David O. Oyedepo of the Living Faith Church Worldwide (Winners' Chapel), Nigerian pastor Temitope Balogun Joshua (TB Joshua) of The Synagogue, Church of All Nations (SCOAN), Nigerian-born pastor Chris Oyakhilome of Christ Embassy, South African televangelist pastor Paseka Motsoeneng (Mboro) of Incredible Happenings, South Africa-based Malawian prophet Shepherd Bushiri of the Enlightened Christian Gathering (ECG) and many others. The grass and petrol pastor, Daniel Lesego of Rabboni Centre Ministries is one of the emerging and controversial pastors in Tshwane. Speaking of the Nigerian context, which is relevant elsewhere in Africa, Umoh (2013:656) concluded that 'religion appears to be the most lucrative business today'.

It is the gospel which is paradoxically placed: In his article, 'The Pentecostal gospel of prosperity in African contexts of poverty: An appraisal', Togarasei (2011) concluded that prosperity gospel is thriving in the context in which it is paradoxically placed because of extreme poverty. Komolafe (2004:220) adds that: '[t]he contours of 'prosperity gospel' portray an attempt to project a collective perception of victorious living in an age of socio-economic and political decline'.

It is anchored in the spirit of 'name it, claim it' syndrome: It is asserted that: '[t]he gospel of prosperity therefore teaches that all resources are there for the people to claim them' (Togarasei 2011:344). The bluff with prosperity gospel is that African Christians who have embraced this message continue to 'name it', whilst their pastors are the ones 'claiming it'. Prophets of prosperity gospel continue to live conspicuous materialistic lifestyles in affluent suburbs and drive the most expensive cars on the market, whilst their congregants are drowning in the triple unholy alliance of poverty, unemployment and inequality. According to Umoh (2013:665), '[t]hey [the poor] continue to hope against hope, even in their hopelessness'.

It is highly commercialised: We are going to expand more on this aspect when dealing with the economics of the prosperity gospel below; however, at this point in time we need to note that commercialisation of the gospel under the disguise of prosperity gospel, promoting the culture of consumerism to unsuspecting and gullible followers, is causing a serious stir in South Africa that has prompted the CRL Rights Commission to investigate this very aspect of our religiosity as African Christians (Kgatle 2017:1).

It is explicitly linked with 'deliverance' theology (Gifford 2004:172). Sin and demonic powers are to blame when one is not receiving the promised prosperity. Gifford (2004:172) adds that: 'it is these spiritual forces that are holding me back from the success and wealth that are my right as a Christian'. Whilst members are encouraged to pray and hold all night prayers, the emphasis is on the spiritual powers of deliverance which the 'anointed man of God' possess. Gifford (2004) captures this as follows:

An 'anointed man of God' could release your blockage. He did not need a questionnaire. He often did not require you to tell him your problem; both the problem and the remedy are either evident to him because of his gifts, or are revealed to him. In the past few years this anointed man of God, or prophet, has become the standard means of deliverance. Often before the suppliant speaks (often before one knows one is a suppliant), the prophet can tell what is the spiritual cause of 'stagnation', and can affect the deliverance right there. (p. 173)

It has gone virtual and viral. The growth of prosperity gospel in Africa is fuelled by the use of media. Recently Kgatle (2018:1) presented a missiological perspective on the use of Facebook and its impact on the emergence of prophetic churches in southern Africa. Another dimension of this media is television. The Trinity Broadcasting Network channel continues to broadcast ambassadors or prophets of the prosperity gospel week in and week out. Viewers are not only promised abundance in terms of material gains and or health, they are also encouraged to 'touch the screen' and connect with the 'anointed man of God' for them to receive their anointing or blessings. Those who benefit from these services are encouraged to contribute financially towards the sustenance of such ministries.

It is highly sensationalised. Testimonies of claims to have received one's health and or wealth are well recorded and publicised in both print and electronic media. Church services within this movement are also flooded by such testimonies. Gifford (2004) asserts that:

Testimonies are an important aid in establishing what this new Christianity is about. Besides the continual stream of testimonies over the airwaves and the readily proffered testimonies of Christians you meet, a good many of these churches have time within services for testimonies from members. The testimonies almost invariably focus on the material realm, on finances, marriage, children, visas, jobs, promotion, [and] travel. Only a small fraction, perhaps $10 \%$, refer[s] to moral reform or deliverance from laziness or drink. Testimonies support the contention that these churches are about success in the way described above. (p.173)

\section{The economics of prosperity gospel}

Sowing and watering the seeds of faith is one of the basic tenets of the theology underpinning prosperity gospel. It is asserted that: 'The new-Pentecostal churches emphasize the seed-faith principle of sowing and reaping' (Ayegboyin 2006:78). The reason for giving therefore is grounded on the blessing motif. It is asserted: 'According to the prosperity gospel Christians who decide to give are sure of God's blessings or happiness. Giving is depicted as a means of enjoying happiness' (Gbote \& Kgatla 2014:5). 
Prosperity gospel is highly commercialised. According to Ayegboyin (2006):

Apart from the 'give and prosper messages' in some of the prosperity gospel ministries, there is full-scale commercialization of the Gospel through the sale of 'break-through handkerchiefs' (called mantles), anointing oil, prayer books and vow-making. (p. 78)

In the South African context, the commercialisation of the gospel has led the Commission for the Promotion and Protection of the Rights of Cultural, Religious and Linguistic Communities (CRL Rights Commission) to institute an official investigation on some of the expressions of the prosperity gospel by prosperity gospel preachers (Kgatle 2017:1; Niemandt 2017:204). The commission had to probe how churches are generating and spending their revenues.

Prosperity gospel has given birth to the culture of greed and consumption. Prophecies are given to business persons about their prosperity, but the rationale behind this is that when they succeed, the prophets will also prosper. The severity of the matter is noted by Ayegboyin (2006:81) as follows:

Some rush into business situations based on such personal prophecy because they believe such prophecies are harbingers of prosperity. However, quite a number of them end up giving out the little they have only to wait endlessly for a hundred-fold multiplication of what they have given. Some prophets are later discovered to be charlatans who are just making merchandise of the gift of God. Kgatle (2017:6) mentions some of these prophets, namely, Lesego Daniel, Lethebo Rabalago, Penuel Mnguni and Paseka Motsoeneng, who have abused church members in the name of religion.

\section{Ubuntu as an antidote to greed culture in prosperity gospel Ubuntu as the African philosophy of life:
muthu ndi muthu nga vhathu}

Ubuntu as the African philosophy of life has been expressed in different languages. Gathogo (2008) summarises in this way:

As a spiritual foundation of African societies, Ubuntu is a unifying vision or worldview enshrined in the Nguni maxim Umuntu ngumuntu ngabantu, that is, 'a person is a person through other persons'. This Ubuntu concept is also found in other African communities, even though there are different vocabularies and phrases that are used to describe it; and it will suffice to illustrate it by citing a few examples. The equivalent of it is seen in a Kikuyu idiom, which says: Mundu ni mundu ni undu wa andu, that is, 'a human being is a person because of the other people'. The same can be said of the Sotho whose idiom says: Motho ke motho ka batho ba bang, and with similar translations to those of other African communities. It is also the same, as: munhu munhu nekuda kwevanhu, used among the Shona people of Zimbabwe. (p. 46)

Although Ubuntu is expressed in different languages, there exists a common bond between all people and it is through this bond, through interaction with fellow human beings, that humanity discovers human qualities. Or as the Zulus would say Umuntu Ngumuntu Ngabantu, which means that a person is a person through other persons. Humanity is affirmed when there is an acknowledgement of the humanity of others. It speaks of the fact that one's humanity is caught up and is inextricably bound up in others. I am human because I belong (Munyaneza 2009:101).

In governance, for example, botho/ubuntu was best described by the saying, kgosi ke kgosi ka batho, namely, that a ruler can only rule in consultation with people, or could only rule through people. Accompanying this ethic of valuing community in governance were the sayings that, mafoko a kgotla a mantle otlhe and mmualebe oabo o bua la gagwe or that in the public court/meeting everyone must be free to express their views. It is also held that kgosi thothobolo e olela matlakala or that a public leader or king, like a dumping site, should welcome and hear all people. These sayings affirm the dignity of both the individual and the community (Dube 2016:4).

Kgosi ke kgosi ka batho in a church setting can be interpreted as Moruti ke Moruti ka Phutego, namely, that a pastor can only lead the congregation in consultation with the congregants. However, this is not the case in many congregations where pastors lead by themselves and take key decisions without consulting the congregants. Hence, we say here that Ubuntu is an antidote of the culture of greed in prosperity gospel. In Ubuntu, the leader of the congregation needs to value people regardless of their age, race, ethnicity, social status and so on.

Ubuntu refers to a set of ideals that guide and direct the patterns of life, which involve being neighbourly and having some social consciousness (Mnyaka 2003:154). Ubuntu recognises the rights and the responsibilities of all people, whether individual or collective. It promotes social and individual well-being and wholeness. It is a concept which attempts to describe the relationship of a person as beingwith-others. It sets the limits or recommendations of what being-with-others entails or requires. It encourages persons to open themselves to others, to learn of others as they learn about themselves too (Lenkabula 2008:379).

Ubuntu highlights the importance of values in life, other than capital, self-interest and individual autonomy, as the perceived values or motivation. It emphasises abundant life grounded on considerations beyond accumulation of capital, monopolisation, hoarding and concentration of wealth, power and economic possibilities (Lenkabula 2010:114). Based both on the community and the person because it was founded on dialogue and reciprocity, the group had priority over the individual without crushing him/her, but allowing him/her to blossom as a person (Battle 2010:427).

The philosophy of Ubuntu is one of mutual concern, care and sharing that holds out the promise of eradicating the preventable and deadly poverty that currently envelops most of Africa (Ramose 2006:15). Ubuntu is a philosophy that places communal interests above those of the individual, and 
where human existence is dependent upon interaction with others (McDonald 2010:139). To be human is to participate in life and respect the conditions that make life possible. To participate in life means ultimately to participate in the fellowship of the community. It emphasises solidarity rather than activity, and the communion of persons rather than their autonomy. Personhood is identified by an individual's interaction with other persons; however, it does not eliminate personal identity (Forster 2010:250).

Ubuntu has a lot to contribute to the building of a healthy world community and to the development of an 'expansive vision' of human well-being and flourishing. Indeed, from a post-colonial perspective, Ubuntu, as a form of indigenous knowledge, is a great resource for bolstering the identity of African people and empowering them, in the current context of stifling globalisation, to find their own voice and use it to contribute to their own well-being and to the well-being of the world. There is great wisdom in Ubuntu for our life together as a world community (Nyengele 2014:26). In addition, Ubuntu, as a form of indigenous knowledge and African philosophy has the ability to reverse the greed culture in prosperity gospel, whereby the income in most churches will benefit everyone including the poor. At present, in prosperity gospel, only pastors benefit and no one else.

\section{The development of the theology of Ubuntu}

In this section, the development of the theology of Ubuntu, we have to ask the main question: is Ubuntu a theological concept? In answering this question, Dreyer (2015) opines that there is a natural synergy between theology and Ubuntu. Dreyer continues to say that:

Archbishop Desmond Tutu, who is rooted in a strong Christian tradition and the broader Anglican Fellowship, has regularly preached about the closeness of this relationship. His work and that of other theologians in South Africa has given rise to the idea of 'Ubuntu theology' [Ubuntu] - where ethical responsibility comes with a shared identity. (p. 193)

The theological definition of Ubuntu according to Membematale (2015:274) is reminiscent of the passage from scripture:

Now the whole group of those who believed were of one heart and soul, and no one claimed private ownership of any possessions, but everything they owned was held in common. There was not a needy person among them, for as many as owned lands or houses sold them and brought the proceeds of what was sold. They laid it at the apostles' feet, and it was distributed to each as any had need. (Ac 4:32-35)

The early church of lived up to the concept of sharing with one another.

As a theological concept, Ubuntu holds humanity accountable to one another, whilst honouring the biblical command to love one's neighbour as oneself ( $\mathrm{Lv}$ 19:18; Mk 12:31; Mt 19:1922-1939). It is within this theological context according to Meiring (2007:737) that God expects humanity to advance community well-being whilst protecting the rights of the socially marginalised and the powerless. In the theology of Ubuntu, our relations within the community determine our relationship with God. With the advancement of the community well-being, the theology of Ubuntu can become an antidote to greed culture that has dominated the prosperity gospel.

Battle (2010:427) states that an Ubuntu that is informed by Christian theology stands a good chance of becoming a system that simultaneously places a high value on community whilst honouring the belief that each person is unique and irreplaceable. Barrett (2008:24) reiterates that the notion of Ubuntu can, of course, be strongly linked to theological ideas of human personhood. People are what they are only by virtue of what they give and receive from each other. At the heart of the Christian faith lies the truth that we find our true being only in relationship, supremely in relations of 'self-giving love'. Indeed, the doctrine of the Trinity points to human reality as intended for 'wholeness being-inrelatedness' (see Barrett 2008:24).

However, theology that takes the principles of Ubuntu into account will be challenged on different levels. In terms of content, it will obviously have to tackle issues such as human dignity and reconciliation, and it will have to be prophetic in addressing social ills. It will also have to adapt to different methodologies in order to achieve a theology that makes a difference in post-apartheid South Africa (Cilliers 2008:12). In addition, this theology must shy away from becoming a victim of traditional thinking. In this regard, the Ubuntu theology needs to move from the 'zombie categories' of orthodoxy, that is, clericalism and the selfculture of individualism and introspection, to the dynamic categories of orthopraxy, that is, the systemic and relational interconnectedness of habitus as introspection (Louw 2011:183).

Building on the principles listed above, there needs to be a new emphasis on holistic theology expressed in the interconnectedness of life and convergence. Holistic theology so expressed manifests a theo-praxis, which is exemplified by Ubuntu. Such a theology should, among other things, speak to the following:

- issues of memory, shame and guilt of the past, enabling liberation for all God's people and creation

- the denial of the dignity and sanctity of people which leads to issues of identity and belonging

- privatization and commodification of life and elements of life, such as water, land, knowledge, etc.

- reaffirmation of the lived experience of people and cultures (Africa Focus 2007:1).

\section{Ubuntu as an antidote of the culture of greed}

The theology of Ubuntu is or can become an antidote to the greed culture that dominates prosperity gospel. However, in order to achieve this, the theology of Ubuntu needs to become 
relevant to the community and the people of that community. It does not only have to draw its principles of togetherness and personhood from the Bible but also needs to apply such biblical principles to real-life situations. It needs to draw its foundation from the first church in the book of Acts where people came together and shared everything among themselves.

In addition, Ubuntu needs to embrace five areas of theology that contribute to the whole. The first one is called a theology of life. Unlike prosperity theology, Ubuntu seeks to preserve life rather than to destroy it. Ubuntu also believes that everyone can have a good life instead of the selected few. Dreyer (2015:200) adds that it is important to note that the 'good life' does not only refer to the individual dimension. It also includes the interpersonal and societal components. Dube (2016:3) opines that relationality and respect for humanity is explicit in the understanding that human life cannot be fulfilled unless it is lived within a web of interactions with others.

This brings us to our second theology called the theology of care. Dreyer continues to say that with regard to care and concern for others (solicitude), we have to treat others, as we would like them to treat us. This implies that unlike in prosperity gospel where only the pastor receives everything, we all share the responsibility for 'our togetherness', and this togetherness in turn empowers each individual. It is only in a community that a person finds his or her personal identity and true humanity (see Dreyer 2015:202). Nyengele (2014:10) adds that just as one gains happiness from social support, one can also gain happiness by providing support and care to others.

In connection to care, there needs to be solidarity which is our third theology. Ubuntu as a worldview advocates for a profound sense of group solidarity and emphasises the fact that our true human potentials can only be realised in partnership with others (Nyengele 2014:19). The application of the Ubuntu philosophy optimises the indigenous setting of an African organisation. The Ubuntu philosophy believes in group solidarity, which is central to the survival of African communities. An African is not an individual in isolation but a person living within a community. In a hostile environment, it is only through such community solidarity that hunger, isolation, deprivation, poverty and any emerging challenges can be survived, because of the community's brotherly and sisterly concern, cooperation, care and sharing (Khomba 2011:242).

One of the causalities of prosperity gospel is economic justice. Instead of fighting the triple challenges of unemployment, poverty and inequality, prosperity gospel perpetrates such challenges. In order to counteract such, there is a need for what we call the theology of economic justice. According to Dreyer (2015:201), economic justice is the importance of equality, of distribution and 'fair shares', of the will to live together, of dealing with plurality, the role of power and most importantly justice as the indispensable condition for living together. Economic justice in this context does not refer to legal justice, which forms part of duty ethics, but a sense of justice oriented to the good. Ubuntu documentation (2008:384) adds that economic injustice compels us to urgently explore the possibility of life-giving civilisation which affirms relationships, coexistence, harmony with creation and solidarity with those who struggle for economic justice.

The last one is called a theology of hope and accompaniment. Accompaniment is the process of walking alongside someone and joining with him or her in solidarity. A Theology of Accompaniment refers to how individuals and communities enter into relationship with one another for the sake of fulfilling Christ's message of reconciliation (White 2007:1). In this context, it means that prosperity pastors need to walk with poor people in their churches. Instead of taking from them, they need to give them real hope by being compassionate and attending to their needs. According to Mashau (2014:7), the theology of accompaniment should

TABLE 1: A comparison between prosperity gospel and Ubuntu.

\section{Prosperity gospel}

Accumulation of individual riches.

Poverty and human suffering are the result of $\sin$ and is undesirable among Christians.

Faith and the need to sow the seed by giving is needed for one to receive God's blessings in his or her life. The more you believe and the more you give the more God blesses you.

Churches are run as private and personal business by the lead pastor who passes on the baton to family members as if the church is their inheritance.

The gospel is highly commercialised and merchandises are sold in the church facilities as part of gospel proclamation.

Gospel is highly sensationalised with members expected to share their testimonies of miracles received, including employment promotions, healing and purchase of new cars and houses even when people were declared insolvent by their banks. Faith manipulation which pushes people to believe in the prophet and not God takes place like questionable practices by others of eating grass, drinking petrol,
eating snakes and accepting pastors to spray doom on them in the name of Jesus Christ. Jesus Christ's name is even abused and misused in the process. God must prove himself by working miracles still, including increase in one's financial and physical health.

Selective reading of the Bible to justify one's beliefs, which is text-proofing, is the order to the day.
Ubuntu

Sharing of personal riches with the community, especially those who are needy.

The poor will always be among us and it is the responsibility of the Christian community to love and take care of them by sharing their resources for the well-being of all.

Giving is important but it is in accordance with the measure of faith that one is given by God. God does not reap where he has not sown; and as such Christians have to reflect God's grace in their life by faithfully giving to the Lord in gratitude of what God has already done for them. Communal running of the church with properly constituted structures in line with biblical principles.

Personal calling, commitment and sacrifices are made to bring the gospel to the marginalised communities without exploiting and abusing them, that is, by asking them to pay for the gospel that they are receiving.

Serving the gospel and God's people with great humility is highly emphasised and celebrated. All miracles are accredited to God and all glory goes to God and not a miracle worker or a person that God used to heal or transform someone else's life.

Faith in God alone as revealed in scriptures is highly emphasised. Emphasis is on walking by faith and not by sight and taking whatever God brings your way as is, including pain and suffering in some instances.

God has already proven himself when Jesus Christ died as a ransom for our sins and therefore there is no reason for him to prove himself; what is required is a walk of faith.

Holistic approach to the reading, interpretation and application of the scriptures is highly emphasised. The meaning of one Scripture is confirmed with the comparison of other similar scriptures in the process of searching and finding the truth, even on issues of health and prosperity. 
take into cognisance, the context in which the people live, meaning the poor people.

\section{Encounterological reflection of prosperity gospel and theology of Ubuntu}

In his confession, Methula (2017) identified the biggest problem of prosperity gospel as follows:

As a devoted Pentecostal-Charismatic pastor who attended prosperity churches from 1992 to 2007 till I opened my Pentecostal congregation, my theological outlook was largely influenced by prosperity preachers such as TD Jakes, Joel Osteen, Musa Sono, David Adebayo and others. I listened to their inspirational, motivational and encouraging messages on Trinity Broadcasting Network every morning and every night till I realised that though they can inspire and motivate, the problem is they leave you without a desire and passion for social justice, structural transformation and overcoming the evils of capitalism. (p. 6)

The quest for social justice, structural transformation and overcoming the evils of capitalism as highlighted by Methula above captures the very core of Ubuntu over the spread of prosperity gospel. It shows how prosperity gospel is paradoxically placed with Ubuntu (see Table 1).

\section{Conclusion}

The theology of Ubuntu, if well imagined and developed, can provide an alternative to the theology of affluence prosperity gospel. The theology of Ubuntu is an array of theologies that are knitted together like a rainbow. It is a coat of many colours but one that is able to bring warmth to those who are naked, marginalised, exploited and abused by religious leaders who are prosperity gospel preachers. These colours will include among others:

- theology of life

- theology of care

- theology of solidarity

- theology of economic justice

- theology of hope and accompaniment.

Ubuntu is the theology that Africa needs. The abovementioned array of theologies, knitted together can help the African church to be as discerning against all forms of teaching that seek to exploit and abuse it. At the same time, it will help the church to identify and correct all the wrong teachings associated with prosperity of the gospel with an eye to expose and correct this in the process. In this way, African Christianity will be able to stand against any form of the gospel that seeks to promote the spirit of consumerism and idolisation of material and physical health as the ideal that must be pursued.

\section{Acknowledgements}

The authors would like to acknowledge the financial support received from the University of South Africa.

\section{Competing interests}

The authors declares that they do not have competing interests with regard to the writing of this article.

\section{Authors' contribution}

T.D.M. contributed to prosperity theology and culture of creed sections of the article and M.S.K. contributed toward the Ubuntu sections of the article.

\section{References}

Achunike, H.C., 2007, 'Prosperity preaching in the Nigerian religious space', Nigerian Journal of Social Sciences 4(1), 83-96.

Africa Focus, 2007, Asia/Africa: Ubuntu and Sangsaeng, viewed 28 August 2007, from www.Africafocus.org

Anderson, A., 1987, 'The prosperity message in the eschatology of some new charismatic churches', Missionalia: Southern African Journal of Mission Studies 15(2), 72-83.

Anim, E.K., 2010, 'The prosperity Gospel in Ghana and the primal imagination', Pentvars Business Journal 4(3), 67-77.

Ayegboyin, D., 2006, 'A rethinking of prosperity teaching in the new Pentecostal churches in Nigeria', Black theology 4(1), 70-86. https://doi.org/10.1558/blth 2006.4.1.70

Barrett, P., 2008, 'The quest for Ubuntu in a coming-of-age South Africa-Questions arising from Dietrich Bonhoeffer's latter ideas', Religion and Theology 15(1), 8-27. https://doi.org/10.1163/157430108X308136

Battle, M., 2010, 'Ubuntu: The western world's contribution', Sewanee Theological Review 53(4), 1-12.

Cilliers, J., 2008, 'July. In search of meaning between Ubuntu and Into: Perspectives on preaching in post-apartheid South Africa', Eighth International Conference of Societas Homiletica, Copenhagen, Denmark, 19 July 2008, pp. 1-20.

City Press, 2011, Paparazzi pastors, viewed 30 September 2014, from https://www. news24.com/Archives/City-Press/Paparazzi-pastors-20150429

Dreyer, J.S., 2015, 'Ubuntu', International Journal of Practical Theology 19(1), 189-209. https://doi.org/10.1515/ijpt-2015-0022

Dube, M.W., 2016, 'Botho/Ubuntu: Community building and gender constructions in Botswana', The Journal of the ITC 40(1), 1-22.

Forster, D.A., 2010, 'African relational ontology, individual identity, and Christian theology: An African theological contribution towards an integrated relational ontological identity', Theology 113(874), 243-253. https://doi.org/10.1177/ $0040571 \times 1011300402$

Gathogo, J., 2008, 'African philosophy as expressed in the concepts of hospitality and ubuntu', Journal of Theology for Southern Africa 130(1), 39.

Gbote, E.Z.M. \& Kgatla, S.T., 2014, 'Prosperity gospel: A missiological assessment', HTS Teologiese Studies/Theological Studies 70(1), Art. \#2105, 10 pages.

Gifford, P., 2004, 'Persistence and change in contemporary African religion', Socia Compass 51(2), 169-176. https://doi.org/10.1177/0037768604043004

Hunt, S., 2000. "Winning ways": Globalisation and the impact of the health and wealth gospel', Journal of Contemporary Religion 15(3), 331-347.

Komolafe, S.B., 2004. 'The changing face of Christianity: Revisiting African creativity', Missiology 32(2), 217-238.

Kgatle, M.S., 2017, 'The unusual practices within some Neo-Pentecostal churches in South Africa: Reflection and recommendations', HTS Teologiese Studies/ Theological Studies 73(3), a4656. https://doi.org/10.4102/hts.v73i3.4656

Kgatle, M.S., 2018, 'Social media and religion: Missiological perspective on the link between Facebook and the emergence of prophetic churches in southern Africa', Verbum et Ecclesia 39(1), a1848. https://doi.org/10.4102/ve. v39i1.1848

Khomba, J.K., 2011, 'Redesigning the balanced scorecard model: An African perspective', PhD thesis, University of Pretoria, Pretoria, viewed 22 October 2011, from http://upetd.up.ac.za/thesis/available/etd- 10142011-093347/

LenkaBula, P., 2008, 'Beyond anthropocentricity-Botho/Ubuntu and the quest for economic and ecological justice in Africa', Religion and Theology 15(3), 375-394. https://doi.org/10.1163/157430108X376591

LenkaBula, P., 2010, 'Economic globalisation, ecumenical theologies and ethics of justice in the twenty-first century', Missionalia: Southern African Journal of Mission Studies 38(1), 99-120.

Louw, D.J., 2011, 'Noetics and the notion of "ubuntu"-thinking within an intercultural hermeneutics and philosophical approach to theory formation in practical theology', International Journal of Practical Theology 15(2), 173-192. https://doi. org/10.1515/IJPT.2011.033

Mashau, T.D., 2013, Coming back to the heart of worship: The hour of true and acceptable worship in the African city, AcadSA, Panorama, Western Cape.

Mashau, T.D., 2014, 'Reimagining mission in the public square: Engaging hills and valleys in the African City of Tshwane', HTS Theological Studies 70(3), 01-11. https://doi.org/10.4102/hts.v70i3.2774 
McDonald, D.A., 2010, "Ubuntu bashing: The marketisation of "African values" in South Metz', Review of African Political Economy 37(124), 139-152. https://doi. org/10.1080/03056244.2010.483902

Meiring, A., 2007. 'As below, so above: A perspective on African theology', HTS Teologiese Studies/Theological Studies 63(2), 733-750.

Membe-Matale, R.D.S., 2015. 'Ubuntu theology', The Ecumenical Review 67(2), 273-276.

Methula, D.W., 2017, 'Decolonising the commercialisation and commodification of the university and theological education in South Africa', HTS Teologiese Studies/ Theological Studies 73(3), a4585. https://doi.org/10.4102/hts.v73i3.4585

Mnyaka, M.M.N., 2003, 'Xenophobia as a response to foreigners in post-apartheid South Africa and post-exilic Israel: A comparative critique in the light of the
gospel and Ubuntu ethical principles', Doctoral dissertation submitted in the discipline of theological ethics, Department of Practical Theology, University of discipline of
South Africa.

Munyaneza, A., 2009, '“Ubuntu" and mother's old black Bible', Cultural Encounters $5(1), 99-102$.

Niemandt, C.J.P., 2017, 'The prosperity gospel, the decolonisation of theology, and the abduction of missionary imagination, Missionalia 45(3), 203-219. https://doi. org/10.7832/45-3-199

Nyengele, M.F., 2014, 'Cultivating Ubuntu: An African postcolonial pastoral theological engagement with positive psychology', Journal of Pastoral Theology 24(2), 4-1. https://doi.org/10.1179/jpt.2014.24.2.004
Obadare, E., 2016, "Raising righteous billionaires": The prosperity gospel reconsidered', HTS Teologiese Studies/Theological Studies 72(4), a3571. https:// doi.org/10.4102/hts.v72i4.3571. 1-8p

Quayesi-Amakye, J., 2011, 'Prosperity and prophecy in African Pentecostalism', Journal of Pentecostal Theology 20, 291-305. https://doi.org/10.1163/17455 2511X597161

Ramose, M.B., 2006, 'Philosophy and Africa's struggle for economic independence', Politeia 25(1), 3-17.

Resane, K.T., 2017, “'And they shall make you eat grass like oxen" (Daniel 4:24): Reflections on recent practices in some new Charismatic churches', Pharos Journal of Theology 98(1), 1-17.

Togarasei, L., 2011, 'The Pentecostal gospel of prosperity in African contexts of poverty: An appraisal', Exchange 40(1), 336-350. https://doi.org/10.1163/157254311X600744

Ubuntu Documentation, 2008, 'Bringing together Ubuntu and Sangsaeng. A journey towards life giving civilization, transforming theology and the ecumenism of the 21 st century', International Review of Mission 97, 384-385.

Umoh, D., 2013, 'Prosperity gospel and the spirit of capitalism: The Nigerian story', African Journal of Scientific Research 12(1), 654-666.

White, R., 2007, 'Walking together in solidarity: A theology of accompaniment', Elcayment, 1-7, viewed 01 December 2017, from www.elcayment.org

Young, P.R., 1996, 'Prosperity teaching in an African context', Africa Journal of Evangelical Theology 15(1), 3-18. 